\title{
CHEMICAL CHARACTERIZATION AND EVALUATION OF ANTIBACTERIAL, ANTIFUNGAL, ANTIMYCOBACTERIAL, AND CYTOTOXIC ACTIVITIES OF Talinum paniculatum
}

\author{
Luis F.C. DOS REIS(1), Cláudio D. CERDEIRA(2), Bruno F. DE PAULA(1), Jeferson J. da SILVA(2), Luiz F.L. COELHO(2),
} Marcelo A. SILVA(1), Vanessa B.B. MARQUES(3), Jorge K. CHAVASCO(2) \& Geraldo ALVES-DA-SILVA(1)

\begin{abstract}
SUMMARY
In this study, the bioactivity of Talinum paniculatum was evaluated, a plant widely used in folk medicine. The extract from the T. paniculatum leaves (LE) was obtained by percolation with ethanol-water and then subjecting it to liquid-liquid partitions, yielding hexane (HX), ethyl acetate (EtOAc), butanol $(\mathrm{BuOH})$, and aqueous (Aq) fractions. Screening for antimicrobial activity of the LE and its fractions was evaluated in vitro through broth microdilution method, against thirteen pathogenic and non-pathogenic microorganisms, and the antimycobacterial activity was performed through agar diffusion assay. The cytotoxic concentrations $\left(\mathrm{CC}_{90}\right)$ for LE, HX, and EtOAc were obtained on BHK-21 cells by using MTT reduction assay. The LE showed activity against Serratia marcescens and Staphylococcus aureus, with Minimum Inhibitory Concentration (MIC) values of 250 and $500 \mu \mathrm{g} / \mathrm{mL}$, respectively. Furthermore, HX demonstrated outstanding activity against Micrococcus luteus and Candida albicans with a MIC of $31.2 \mu \mathrm{g} / \mathrm{mL}$ in both cases. The MIC for EtOAc also was $31.2 \mu \mathrm{g} / \mathrm{mL}$ against Escherichia coli. Conversely, BuOH and Aq were inactive against all tested microorganisms and LE proved inactive against Mycobacterium tuberculosis and Mycobacterium bovis as well. Campesterol, stigmasterol, and sitosterol were the proposed structures as main compounds present in the EF and HX/EtOAc fractions, evidenced by mass spectrometry. Therefore, LE, HX, and EtOAc from T. paniculatum showed potential as possible sources of antimicrobial compounds, mainly $\mathrm{HX}$, for presenting low toxicity on BHK-21 cells with excellent Selectivity Index $\left(\mathrm{SI}=\mathrm{CC} / \mathrm{MIC}_{90}\right.$ of 17.72 against C. albicans.
\end{abstract}

KEYWORDS: Talinum paniculatum; Antimicrobial activity; C. albicans; Cytotoxicity; Mass spectrometry.

\section{INTRODUCTION}

In recent years, the necessity of research for new antimicrobial agents has increased due to the global emergence and spread of antimicrobialresistant microorganisms. The discovery of antimicrobial agents to treat infections involving resistant microorganisms is highly desirable, however, it is also a challenging task $\mathrm{k}^{29}$. Indeed, although there are parallel endeavors to solve the global public health threats represented by both antimicrobial resistance and lack of development of new antimicrobials, the urgency for more effective results is still demanded for ${ }^{16,22}$.

As examples of the serious problem represented by the antimicrobial resistance, Staphylococcus aureus is the main cause of death in hospitals in the United States of America, in part because of multi-resistance to antimicrobials agents ${ }^{3}$. Bacteria such as Pseudomonas aeruginosa and Escherichia coli, and fungi such as Candida albicans have also acquired resistance to antimicrobials agents, consequently, infectious diseases caused by these microorganisms are responsible by high mortality rates $^{3,15}$. Moreover, Mycobacterium tuberculosis, the causative agent of tuberculosis (TB), has shown resistance to first-and second-line anti-TB drugs, and globally, TB is one of the leading causes of mortality from infectious disease ${ }^{13}$, with an urgent need for a new, affordable, and more effective TB treatment.

Plants are among the possible sources of new compounds for drug discovery. They have been used for therapeutic purposes since ancient times, and nowadays, plants play a crucial role in research for new therapeutic alternatives in medical practice, either by being useful as herbal medicine or as sources of new bioactive substances with antimicrobial action for fighting infections. In addition, in discovering drugs from natural sources, they may also provide lead compounds for rational chemical synthesis and structure-activity relationship studies $^{16,18,25}$.

In this context, Brazilian biodiversity has great potential to be explored, of which is part Talinum paniculatum (Jacq.) Gaertner [synonyms: Talinum patens (L.) Willd, Talinaceae Family], popularly known in Brazil as "Erva-gorda" and "Língua-de-vaca", and in other 


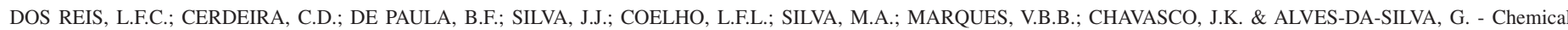
characterization and evaluation of antibacterial, antifungal, antimycobacterial, and cytotoxic activities of Talinum paniculatum. Rev. Inst. Med. Trop. Sao Paulo, 57(5): 397-405, 2015.

countries as "Java ginseng" and "Jewels of opar". Originally from tropical America, T. paniculatum is widely spread throughout all Brazilian territory. Morphologically, the whole plant can reach up to $60 \mathrm{~cm}$ and its leaves are opposite, petiolate, fleshy, succulent, and with smooth-edged. The leaves from T. paniculatum are often used as a green leafy vegetable for human consumption ${ }^{20}$.

T. paniculatum is also used in folk medicine to treat ulcers, as an emollient in gastrointestinal problems treatment, and used typically against a broad spectrum of wounds and skin infections ${ }^{4}$. According to YULIA et al. (2006) $)^{36}$ and PANIZZA $(1998)^{24}$, T. paniculatum has secondary metabolites such as tannins, steroids, and triterpenes. Pharmacological studies have demonstrated estrogenic ${ }^{34}$ and antinociceptive ${ }^{28}$ activities of T. paniculatum.

The limited repertoire of antimicrobials to treat infections caused by mycobacteria, bacteria, and fungi has generated a search for new substances; for that reason, the objective of this study was to evaluate the antimicrobial activity of the crude extract from $T$. paniculatum leaves and its fractions against microorganisms of medical and environmental relevance. Additionally, we performed a toxicity test for T. paniculatum on BHK-21 cells and an analysis of the phytoconstituents from its leaves, focusing in the phytosterol compounds.

\section{METHODS}

Plant material: the $T$. paniculatum leaves were collected near the

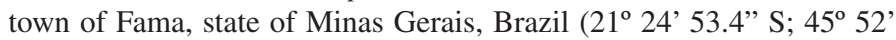
15.8 " W), in the mornings of June, 2012. The botanical identification of the species T. paniculatum (Talinaceae) was performed using proven pharmaco-botanical methods. A sample of plant was stored in the UALF Herbarium at the Federal University of Alfenas (UNIFAL-MG), under the specimen number 2338 .

Obtaining the hydro-alcoholic leaf extract and fractions from $T$. paniculatum: the leaf extract (LE) from T. paniculatum was obtained through the exhaustive extraction method known as simple percolation. The process started by adding the extracting liquid to $200 \mathrm{~g}$ of leaf powder, and letting it seep for two hours outside the percolator. Once the two hours had passed, the percolator (alcohol: water 7:3 v/v) was packed with the mixture. The flow rate of the percolate was $1.0 \mathrm{~mL} / \mathrm{min} /$ $\mathrm{kg}$. After extraction, the fluid extracted was placed in a rotary evaporator under reduced pressure, at a temperature of $45^{\circ} \mathrm{C}$. The extract was then lyophilized to completely remove water and obtain the dry extract (17.0\% of yield from the initial content of the leaves from T. paniculatum). To obtain the fractions, the dried extract was subjected to a liquid-liquid partition with hexane (1:1, v/v [x4]), ethyl acetate (1:1, v/v [6X]), and n-butanol (1:1, v/v [6X]), yielding hexane (HX), ethyl acetate (EtOAc), and butanol $(\mathrm{BuOH})$ fractions, as well as a residue termed aqueous fraction, which SILVA et al. (2004) have previously described ${ }^{32}$.

\section{In vitro assessment of antimicrobial activity}

Microbial strains: the type-strains of microorganisms used were from the American Type Culture Collection (ATCC), and the Microbiology and Immunology Laboratory (LMI) at UNIFAL-MG. These microorganisms are representative of the main groups of mycobacteria, bacteria, and fungi, and display medical and environmental importance. The fungi included
Candida albicans (ATCC 10231) and Saccharomyces cerevisiae (ATCC 2601). The Gram-positive bacteria included Bacillus subtilis (ATCC 6633), Bacillus cereus (ATCC 11778), Micrococcus luteus (ATCC 9341), Enterococcus faecalis (ATCC 51299), and Staphylococcus aureus (ATCC 6538). The Gram-negative bacteria included Escherichia coli (ATCC 25922), Serratia marcescens (LMI-UNIFAL), Pseudomonas aeruginosa (ATCC 27853), Proteus mirabilis (ATCC 25922), Salmonella typhimurium (ATCC 14028), and Enterobacter aerogenes (LMI-UNIFAL). The mycobacteria included Mycobacterium bovis (BCG strain, ATCC 27289) and Mycobacterium tuberculosis (H37Ra strain, ATCC 27294).

Broth microdilution method: minimum inhibitory concentration (MIC) of the LE from T. paniculatum and fractions were determined through broth microdilution against bacteria and fungi, according to methodologies established in M7A6 (CLSI, 2003) and M27A3 (CLSI, 2008) documents ${ }^{7,8}$. Tests were performed on 96-well microplates. At first, the turbidity of microbial suspensions in sodium chloride $0.9 \%$, cultured overnight at $35^{\circ} \mathrm{C}$ for 18 hours, were adjusted according to a McFarland standard (0.5 tube). Next, $100 \mu \mathrm{L}$ of Mueller Hinton broth (MHB) was added per well and, after that, $100 \mu \mathrm{L}$ of either LE or the tested fractions ( $\mathrm{HX}, \mathrm{BuOH}, \mathrm{EtOAc}$ or Aq) were added. Serial dilutions were made with the final concentrations of the LE or fractions ranging from 4000 to 15.6 $\mu \mathrm{g} / \mathrm{mL}$. Finally, $10 \mu \mathrm{L}$ of microorganism was added to each well. The reading was performed visually as previously determined (CLSI, 2003) ${ }^{7}$, wherein the presence of turbidity in the wells after incubation for 24 hours at $37{ }^{\circ} \mathrm{C}$ was considered indicative of bacterial growth. The $\mathrm{MIC}_{100}$ was established as the lowest concentration of the extract or fraction in which no turbidity had occurred. The growth control was composed of $100 \mu \mathrm{L}$ of MHB and $10 \mathrm{~mL}$ of inoculum. The extract control was composed of $100 \mu \mathrm{L}$ of MHB and $100 \mu \mathrm{L}$ of the LE or fraction and the sterility control contained only $100 \mu \mathrm{L}$ of MHB. Chlorhexidine $0.12 \%$ also was used as a positive control.

Antimycobacterial activity: the LE, at a concentration of $50 \mathrm{mg} / \mathrm{mL}$, was evaluated against both the $M$. bovis and $M$. tuberculosis through the agar diffusion assay, according to M24A2 (CLSI, 2008) document and CHAVASCO et al. (2014) $)^{5}$. Regarding controls, Rifampicin $30 \mu \mathrm{g}$ was used as a positive control and distilled water as a negative control.

Agar diffusion assay: screening by agar diffusion assay for antimicrobial activity of the LE and fractions (HX and EtOAc) was performed according to methodology previously proposed ${ }^{5}$. Initially, suspensions of overnight culture of microbial strains were prepared in sodium chloride $0.9 \%$ with a turbidity corresponding to a 0.5 tube of a Mac-Farland scale and inoculated on the surface of culture medium Mueller-Hinton Agar. Then, $40 \mu \mathrm{L}$ of the LE ( $40 \mathrm{mg} / \mathrm{mL}$ ) or fraction $(10 \mathrm{mg} / \mathrm{mL})$ were placed in wells of $4 \mathrm{~mm}$ of diameter confectioned previously on agar. Next, the plates were incubated at $37{ }^{\circ} \mathrm{C}$ for 18 hours. At the end of the incubation period, the antimicrobial activity was evaluated by measuring the growth inhibition zones. Chlorhexidine solution $(0.12 \%)$ as a positive control and distilled water as a negative control were utilized. All tests were performed in triplicate.

Screening of cytotoxic activity: cytotoxicity of the leaf extract and $\mathrm{HX} / \mathrm{EtOAc}$ fractions from $T$. paniculatum was evaluated using the MTT (3-(4,5-dimethylthiazolyl-2)-2,5-diphenyltetra-zolium bromide) reduction assay. In the 96-well microplates, $1.0 \times 10^{4} \mathrm{BHK}-21$ cells (cell lineage from baby hamster kidney) were added to wells containing 0.1 


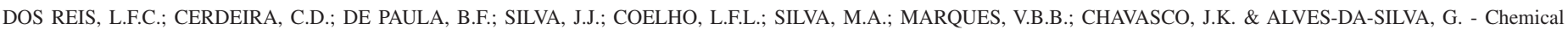
characterization and evaluation of antibacterial, antifungal, antimycobacterial, and cytotoxic activities of Talinum paniculatum. Rev. Inst. Med. Trop. Sao Paulo, 57(5): 397-405, 2015.

$\mathrm{mL}$ of the $\mathrm{L}-15$ medium with $1 \%$ fetal bovine serum. Then, the plates were incubated for 72 hours in an atmosphere containing $5 \% \mathrm{CO}_{2}$ and at $37^{\circ} \mathrm{C}$. After incubation and removal of the medium, decreasing dilutions of the extract and fractions, ranging from 1,200 to $9,375 \mu \mathrm{g} / \mathrm{mL}$ plus the L-15 medium were added and the plates incubated again under the same conditions. For control, only the medium was added to the wells with cells. After that, $10 \mu \mathrm{L}$ of MTT were added to the wells, and the plates were then incubated for four hours to incorporate the reagent. Finally, $100 \mu \mathrm{L}$ of DMSO were added per well for solubilization of formazan and then the absorbance was read at $570 \mathrm{~nm}$ to determine the cytotoxic concentration for $50 \%\left(\mathrm{CC}_{50}\right)$ and $90 \%$ of the cells $\left(\mathrm{CC}_{90}\right)$.

Determining chemical compounds through mass spectrometry (MS): after detecting compounds such as tannin, saponin, and phytosteroid, by preliminary phytochemical screenings, we proceeded to structural elucidation of representative molecules from these groups via mass spectrometry. The analyses of the crude extract (LE), and the hexane and ethyl acetate fractions were performed using the MS technique. The samples were directly injected into mass spectrometer Shimadzu LCMS8030. The selected fragmentation energy was $-20 \mathrm{e} \mathrm{V.}$ Primary scans of LE, HX and EtOAc were made and subsequent second order fragmentation of selected peaks in order to identify the secondary metabolites.

Data analysis: the experiments were performed in triplicate and the mean is presented. $\mathrm{CC}_{50}$ and $\mathrm{CC}_{90}$ were calculated by linear regression, with a dose-effect curve of cells treated with LE, HX, or EtOAc. The absorbance reduction at 50\% and $90 \%$ were compared to a control, with untreated cells. The selectivity index (SI) was calculated according to PROTOPOPOVA et al. (2005), which equals the ratio between $\mathrm{CC}_{90}$ and $\mathrm{MIC}_{100}{ }^{27}$. All data from antimicrobial activity by agar diffusion were presented as mean of the triplicate obtained from experiments and were assessed by Analysis of Variance (ANOVA) and Scott-Knott post hoc testing for multiple comparisons of means (differences were considered to be significant at $p<0.05$ ). The software used was the Sisvar Version 5.3 (DEX-UFLA). Besides agar diffusion and MIC values, quantitative evaluation of antimicrobial activity was performed by percent activity values, which reveal the antimicrobial potential of a particular extract or fraction with a MIC up to $500 \mu \mathrm{g} / \mathrm{mL}$, and the microbial susceptibility index (MSI), which is used to compare the relative susceptibility among the evaluated microorganisms against the extract and fractions with MIC up to $500 \mu \mathrm{g} / \mathrm{mL}^{2}$.

Percent activity (\%) and Microbial Susceptibility Index (MSI) were calculated as follows:

$$
\begin{gathered}
\text { Activity }(\%)=\frac{\begin{array}{c}
\text { No. of susceptible microorganisms } \\
\text { to a specific extract or fraction }
\end{array}}{\text { Total no. of tested microorganisms }} \times 100 \\
\text { NSI }=\frac{\begin{array}{c}
\text { against each microorganisms } \\
\text { Total no. of extracts and fractions }
\end{array}}{\text { agacts and fractions effective }}
\end{gathered}
$$

\section{RESULTS}

The minimum inhibitory concentration (MIC) values of the leaf extract (LE) from $T$. paniculatum and fractions against thirteen medically relevant microorganisms and the data from evaluation of antimycobacterial activity against $M$. tuberculosis and $M$. bovis is presented in Table 1. The LE was active against $S$. marcescens (Gramnegative) and $S$. aureus (Gram-positive), and the hexane (HX) and ethyl acetate (EtOAc) fractions showed considerable inhibitory activity, with MIC values -ranging from 31.2 to $500 \mu \mathrm{g} / \mathrm{mL}$ against some Grampositive and Gram-negative bacteria and against the yeast $C$. albicans. The butanol $(\mathrm{BuOH})$ and aqueous $(\mathrm{Aq})$ fractions were inactive against all tested microorganisms.

Data from Table 1 also shows cytotoxicity $\left(\mathrm{CC}_{50}\right.$ and $\left.\mathrm{CC}_{90}\right)$ for $\mathrm{LE}$, $\mathrm{HX}$, and EtOAc on BHK-21 cells and the Selectivity Index (SI). Data from agar diffusion assay are presented in Table 2. The LE showed inhibition zone significantly higher than chlorexidine $0.12 \%$ against $B$. subtilis and B. cereus $(p<0.05)$. The activity of the LE against $S$. aureus and M. luteus, was equivalent to chlorhexidine $0.12 \%$. The percent activity (\%) and the microbial susceptibility index (MSI, \%) are presented in Figures 1 and 2.

The analysis by mass spectrometry was conducted to scan all compounds in the LE, HX, and EtOAc (presented as supplementary data, Figs. from 4 to 6). The main peaks observed were 401, 413, and 415 $\mathrm{m} / \mathrm{z}$. These peaks correspond to phytosterols found in $T$. paniculatum. Therefore, in order to identify these compounds, a second order fragmentation of the peaks equivalent to 401,413 , and $415 \mathrm{~m} / \mathrm{z}$ was performed (also presented on supplementary data, Figs. from 7 to 9 ).

By interpreting the second order mass spectra, it was possible to propose the structures depicted in Figure 3 (below). For the $401 \mathrm{~m} / \mathrm{z}$ peak, the main second order fragments were 207, 147, and $121 \mathrm{~m} / \mathrm{z}$. The phytosterol compound Campesterol has a molecular mass of 401 $\mathrm{Da}$ and the fragments found can be suggested by its structure. The compound with $413 \mathrm{~m} / z$ was associated to stigmasterol (M+1), which has a molecular mass of $412 \mathrm{Da}$, and the second order peaks corresponding to the fragments of 207 and $\mathrm{m} / \mathrm{z}$ of $269 \mathrm{~m} / \mathrm{z}$. The fragmentation of the compound with $415 \mathrm{~m} / \mathrm{z}$ gave peaks of 355,223 , and $267 \mathrm{~m} / \mathrm{z}$ and complies with the phytosterol known as sitosterol.

\section{DISCUSSION}

The therapeutic use of plants in traditional medicine, based on herbal drugs, plays an essential role in several countries. Additionally, the bioactivity of plants has been attributed to the presence of molecules belonging to selected groups of plant metabolites, most of which are from the secondary metabolism. Accordingly, plants are also potential sources of drug candidates.

In a preliminary phytochemical screening, leaf extract (LE) from $T$. paniculatum was positive for pharmacologically active groups as steroids, saponins, and tannins; the ethyl acetate (EtOAc) fraction for steroids, triterpenes, and saponins; and the hexane (HX) fraction for steroids and triterpenes. The results directed the research for representatives of these phytochemical classes by using mass spectrometry (MS), which is an instrumental technique of great range and importance in the analysis of natural compounds, providing more complete information on the species chemical composition $^{26}$. In our study, campesterol, stigmasterol, and sitosterol were proposed as major compounds in the LE, HX, and EtOAc from T. paniculatum (Fig. 3); similar results were reported by RAMOS et al. $(2010)^{28}$, who identified the phytosterols campesterol, 


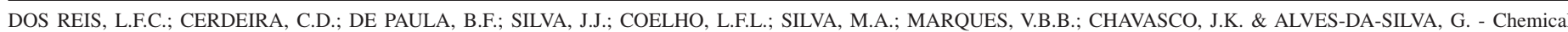
characterization and evaluation of antibacterial, antifungal, antimycobacterial, and cytotoxic activities of Talinum paniculatum. Rev. Inst. Med. Trop. Sao Paulo, 57(5): 397-405, 2015.

Table 1

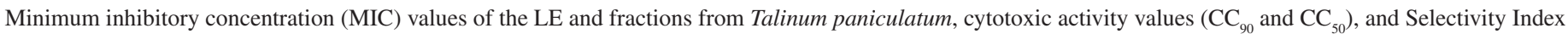
(SI) against the evaluated microorganisms

\begin{tabular}{|c|c|c|c|c|c|c|c|c|c|c|}
\hline \multirow{3}{*}{ Microorganisms } & \multicolumn{4}{|c|}{ Leaf extract } & \multicolumn{4}{|c|}{ Fractions } & \multirow{2}{*}{\multicolumn{2}{|c|}{$\mathrm{Aq}$}} \\
\hline & & & & & & & & & & \\
\hline & $\begin{array}{c}\mathrm{MIC} \\
(\mu \mathrm{g} / \mathrm{mL})\end{array}$ & SI & $\begin{array}{c}\mathrm{MIC} \\
(\mu \mathrm{g} / \mathrm{mL})\end{array}$ & SI & $\begin{array}{c}\mathrm{MIC} \\
(\mu \mathrm{g} / \mathrm{mL})\end{array}$ & SI & $\begin{array}{c}\mathrm{MIC} \\
(\mu \mathrm{g} / \mathrm{mL})\end{array}$ & SI & $\begin{array}{c}\mathrm{MIC} \\
(\mu \mathrm{g} / \mathrm{mL})\end{array}$ & SI \\
\hline
\end{tabular}

\section{Gram positive}

\begin{tabular}{|c|c|c|c|c|c|c|c|c|c|}
\hline B. cereus & $\mathrm{N}$ & NA & 250 & 2.21 & 500 & 0.61 & $\mathrm{~N}$ & NA & $\mathrm{N}$ \\
\hline B. subtilis & $\mathrm{N}$ & NA & 250 & 2.21 & 500 & 0.61 & $\mathrm{~N}$ & NA & $\mathrm{N}$ \\
\hline M. luteus & $\mathrm{N}$ & NA & 31.2 & 17.72 & 500 & 0.61 & $\mathrm{~N}$ & NA & $\mathrm{N}$ \\
\hline E. faecalis & $\mathrm{N}$ & NA & $\mathrm{N}$ & NA & $\mathrm{N}$ & NA & $\mathrm{N}$ & NA & $\mathrm{N}$ \\
\hline S. aureus & 500 & 2.76 & 250 & 2.21 & 250 & 1.2 & $\mathrm{~N}$ & NA & $\mathrm{N}$ \\
\hline
\end{tabular}

Gram-negative

E. aerogenes

E. coli

S. marcescens

$\begin{array}{lll}\mathrm{N} & \mathrm{NA} & 500\end{array}$

1.11

NA 500

1.11

70

2.21

31.2

4.33

$\mathrm{N}$

250

9.71

$\mathrm{N}$

NA

$\mathrm{N}$

NA

$P$. aeruginosa

250

$5.52 \quad 250$

2.21

500

1.22

$\mathrm{N}$

NA

N

NA

P. mirabilis

N NA 500

1.11

500

0.61

N

NA

N

NA

S. typhimurium

$\mathrm{N} \quad \mathrm{NA} \quad \mathrm{N}$

NA

$\mathrm{N}$

0.61

$\mathrm{N}$

NA

N

NA

Fungi

C. albicans

S. cerevisiae

$\begin{array}{lll}\mathrm{N} & \mathrm{NA} & 31.2\end{array}$

31.2
$\mathrm{~N}$

17.72

130
$\mathrm{~N}$

NA

N

NA

$\mathrm{N}$

NA

$\mathrm{N}$

NA

$\mathrm{N}$

NA

\section{Mycobacteria}

\begin{tabular}{|c|c|c|c|c|c|c|c|c|c|c|}
\hline M. bovis & $\mathrm{N}$ & NA & ---- & NA & ---- & NA & ---- & NA & ---- & NA \\
\hline M. tuberculosis & $\mathrm{N}$ & NA & ---- & NA & ---- & NA & ---- & NA & ---- & NA \\
\hline
\end{tabular}

\section{Cytotoxicity}

$\mathrm{CC}_{90}(\mu \mathrm{g} / \mathrm{mL})$

1380

553

$\mathrm{CC}_{50}(\mu \mathrm{g} / \mathrm{mL}$

460

230

303
170

2.33

N

NA

N

NA

NA

N

NA

$\mathrm{N}$

NA

Subtitle: $\mathrm{SI}=\mathrm{CC}_{90} / \mathrm{MIC}_{100} ; \mathrm{NA}$ : Not applicable; N: Lack of inhibition of microbial growth at the maximum concentration of the extract/fraction used in the experiment; ----: Not Evaluated; LE: Hydroalcoholic leaf extract; HX: Hexane fraction; EtOAc: Ethyl acetate fraction; BuOH: Butanol fraction; Aq: Aqueous fraction.

$\beta$-sitosterol, and stigmasterol.

Currently, given the presence of antimicrobial-resistant microorganisms and consequently the necessity for antimicrobials with original action, screening of plants as an approach to antimicrobial discovery can help in the search of new compounds. AWOUAFACK et al. (2013), among other authors ${ }^{1}$, have reported that plant extracts or fractions assessed by using broth microdilution have promising inhibitory potential whether they demonstrate antimicrobial activity at concentrations up to $100 \mu \mathrm{g} / \mathrm{mL}$ and moderate inhibitory activity between 100 and $625 \mu \mathrm{g} / \mathrm{mL}$. Thus, the LE from T. paniculatum showed moderate activity ( 250 and $500 \mu \mathrm{g} / \mathrm{mL}$, Table 1 ), and $\mathrm{HX}$ and EtOAc fractions (HX showed MIC value of $31.2 \mu \mathrm{g} / \mathrm{mL}$ and EtOAc of 31.2 and $70 \mu \mathrm{g} /$ $\mathrm{mL}$, Table 1) were considered promising sources in the search for new substances with antimicrobial action. The butanol and aqueous fractions were considered inactive.

The active fractions from $T$. paniculatum, related to antimicrobial activity, HX and EtOAc, concentrate nonpolar compounds, such as phytosterols, as demonstrated in this study, and by RAMOS et al., $2010^{28}$ and THANAMOOL et al., 2013 ${ }^{34}$. The antimicrobial effect of such compounds has been cited in literature $\mathrm{e}^{10,12}$. The actions of nonpolar compounds are the result of mechanisms involving an alteration in the fungal or bacterial cell membrane, leading to a loss of permeability and to accumulation of toxic substances, which disrupt the cell metabolism and activate the cytolytic pathways ${ }^{31}$. The tannins found during the preliminary screening have been associated with disruption of membranes, in addition to chelation or precipitation of essential substances to the microorganisms, such as proteins ${ }^{30}$. Interestingly, whereas the HX and EtOAc fractions showed antimicrobial activity and 


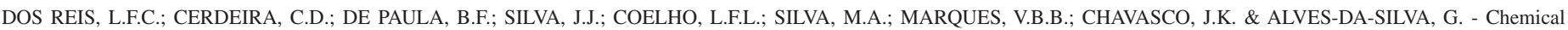
characterization and evaluation of antibacterial, antifungal, antimycobacterial, and cytotoxic activities of Talinum paniculatum. Rev. Inst. Med. Trop. Sao Paulo, 57(5): 397-405, 2015.

Table 2

Mean of the growth inhibition zone (diameter in mm) of the LE, HX, and EtOAc from Talinum paniculatum

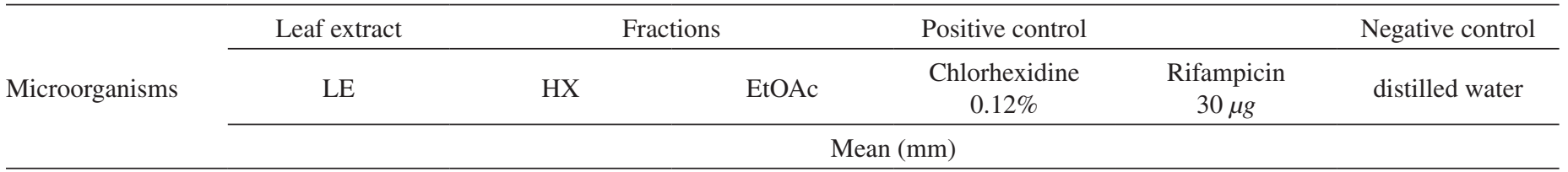

\section{Gram positive}

B. cereus

$27.00^{\mathrm{e}}$

$3.00^{\mathrm{b}}$

$7.00^{\mathrm{b}}$

$12.00^{\mathrm{c}}$

NA

$0.00^{\mathrm{a}}$

B. subtilis

$24.00^{\mathrm{e}}$

$7.00^{\mathrm{b}}$

$7.00^{\mathrm{b}}$

$16.00^{\mathrm{d}}$

NA

$0.00^{\mathrm{a}}$

M. luteus

$17.00^{\mathrm{d}}$

$5.00^{\mathrm{b}}$

$2.00^{\mathrm{b}}$

$18.00^{\mathrm{d}}$

NA

$0.00^{\mathrm{a}}$

E. faecalis

$0.00^{\mathrm{a}}$

$0.00^{\mathrm{a}}$

$0.00^{\mathrm{a}}$

$14.00^{\mathrm{c}}$

NA

$0.00^{\mathrm{a}}$

S. aureus

$17.00^{\mathrm{d}}$

$2.00^{\mathrm{b}}$

$8.00^{\mathrm{b}}$

$16.00^{\mathrm{d}}$

NA

$0.00^{\mathrm{a}}$

\section{Mycobacteria}

\begin{tabular}{|c|c|c|c|c|c|c|}
\hline M. bovis & $0.00^{\mathrm{a}}$ & ---- & ---- & NA & 26.00 & $0.00^{\mathrm{a}}$ \\
\hline M. tuberculosis & $0.00^{\mathrm{a}}$ & ---- & ---- & NA & 26.00 & $0.00^{\mathrm{a}}$ \\
\hline
\end{tabular}

Subtitle: LE: Hydroalcoholic leaf extract; HX: Hexane fraction; EtOAc: Ethyl acetate fraction; Means followed by different letters show difference from each other according to Scott \& Knott test $(p<0.05)$; Tests by agar diffusion performed with LE at a concentration of $50 \mathrm{mg} / \mathrm{mL}$ against Mycobacteria and at a concentration of $40 \mathrm{mg} / \mathrm{mL}$ against Gram positive bacteria; Fractions (HX or EtOAc) were tested at a concentration of $10 \mathrm{mg} / \mathrm{mL}$; NA: Not applicable; ----: Not Evaluated.

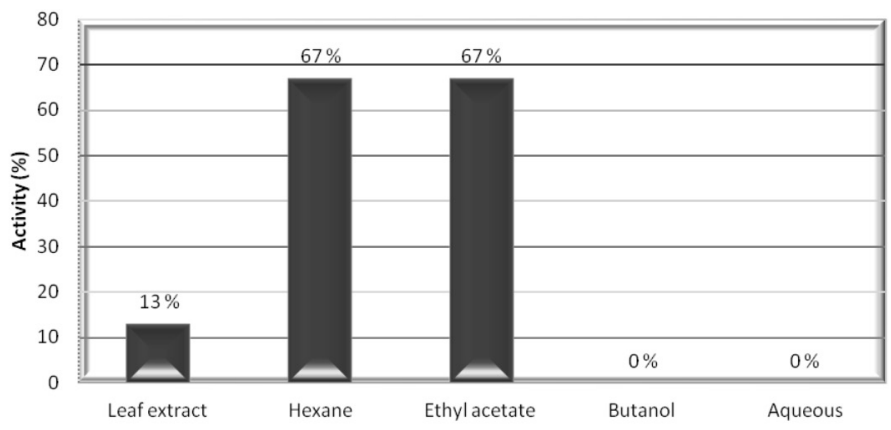

Fig. 1 - Percent activity of the LE and fractions from Talinum paniculatum which showed MIC lower than $500 \mu \mathrm{g} / \mathrm{ML}$.

phytosterols in their chemical composition, butanol and aqueous fractions were inactive and phytosterols were not detected.

Regarding the evaluation of antimicrobial activity by using agar diffusion, the HX and EtOAc fractions showed weak activity at high concentrations against some Gram-positive microorganisms (Table 2), and no activity against all evaluated Gram-negative microorganisms (data not shown). Parallel, these fractions exhibited excellent inhibitory activity at low concentrations through broth microdilution (Table 1). This can be explained, at least in part, by the fact that these fractions are less polar, restricting their diffusions throughout the agar (more polar), differently from the broth microdilution method, which allows direct contact between microorganism and the fraction. This restriction imposed by the agar diffusion assay precludes its use in antimicrobial evaluation from nonpolar fractions. Considering this important factor, broth microdilution assay would be more appropriate.

The percent activity (Fig. 1) shows the antimicrobial potency of an

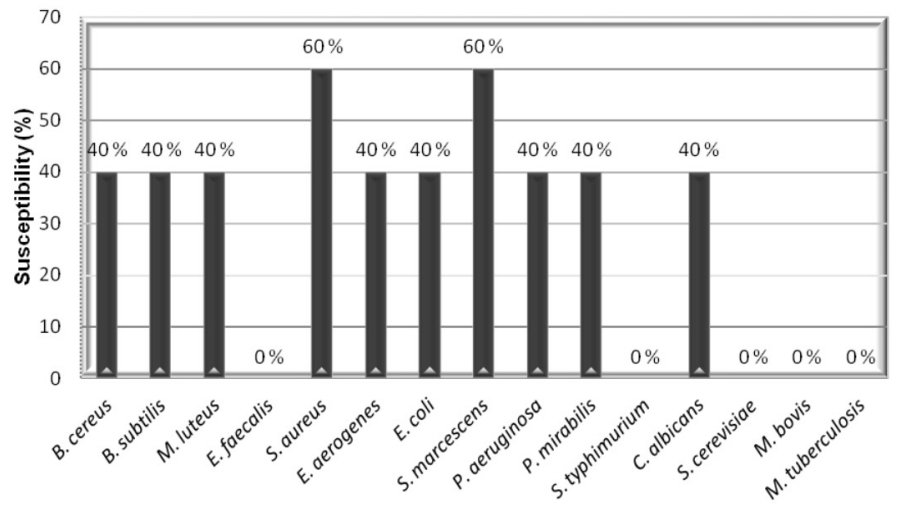

Fig. 2 - Microbial susceptibility index (MSI, \%) for microorganisms against LE and fractions from Talinum paniculatum which showed MIC lower than $500 \mu \mathrm{g} / \mathrm{mL}$.

extract or fraction in particular, and it takes into account the number of susceptible microorganisms, whereas MSI (Fig. 2) compare the relative susceptibility among the microorganisms, with values ranging from ' 0 ' (resistant to all extracts/fractions evaluated) to '100' (susceptible to all extracts/fractions evaluated). Figures 1 and 2 indicate that $\mathrm{HX}$ and EtOAc fractions were considered the most active, both displaying activity against $67 \%$ of the evaluated microorganisms, and for the MSI, S. aureus and $S$. marcescens were considered the most susceptible microorganisms, being inhibited by $60 \%$ of the tested extract/fractions.

From toxicity data $\left(\mathrm{CC}_{90}\right.$ and $\mathrm{MIC}_{100}$ values for $\mathrm{LE}, \mathrm{HX}$, and EtOAc, the selectivity index (SI) for each microorganism was obtained. The HX against M. luteus and C. albicans had a excellent SI of 17.72, making it suitable for secondary screening studies aiming the isolation of compounds with promising antimicrobial activity according to KLEYMANN et al. $(2004)^{17}$, since selective toxicity on microbial cells 
DOS REIS, L.F.C.; CERDEIRA, C.D.; DE PAULA, B.F.; SILVA, J.J.; COELHO, L.F.L.; SILVA, M.A.; MARQUES, V.B.B.; CHAVASCO, J.K. \& ALVES-DA-SILVA, G. - Chemical characterization and evaluation of antibacterial, antifungal, antimycobacterial, and cytotoxic activities of Talinum paniculatum. Rev. Inst. Med. Trop. Sao Paulo, 57(5): 397-405, 2015.
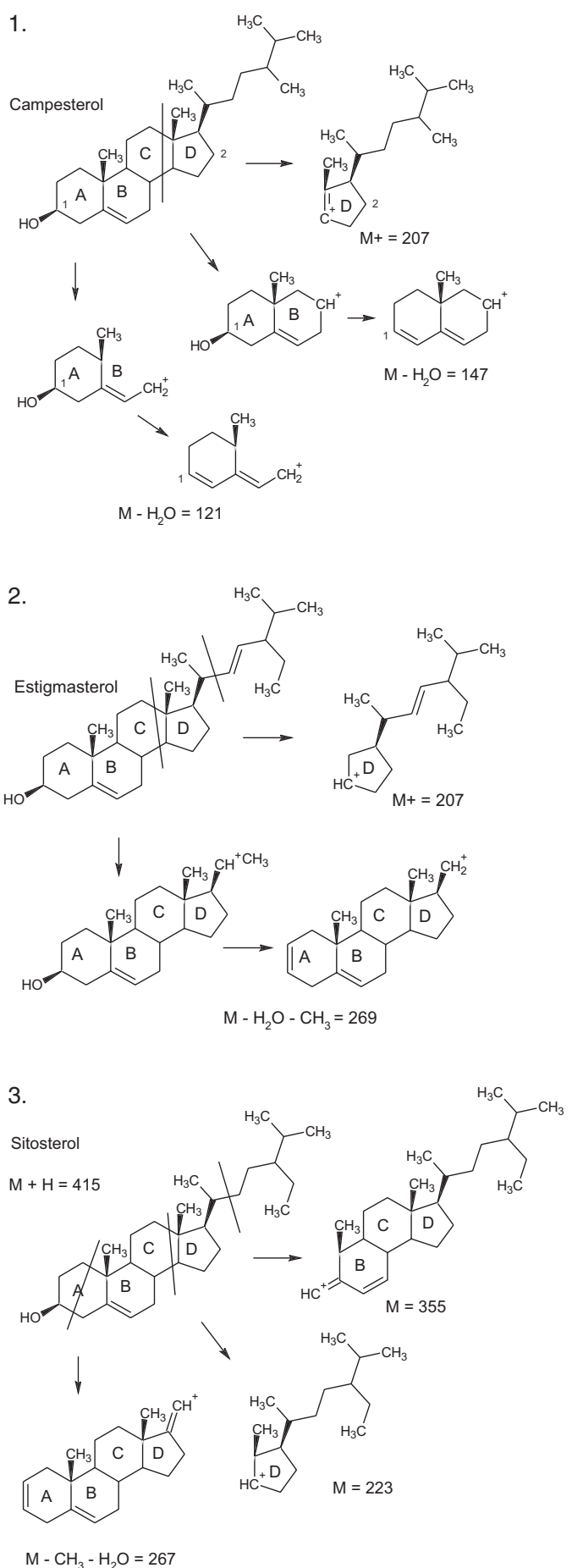

1. - Campesterol: $(3 S, 8 S, 9 S, 10 R, 13 R, 14 S, 17 R)-17-[(2 R, 5 R)-5,6$-dimetileptan-2-il]-10,13dimetil-2,3,4,7,8,9,11,12,14,15,16,17-dodecaidro-1 $H$-ciclopenta[ $a]$ fenantren-3-ol; 2. - Estigmasterol: $(3 S, 8 S, 9 S, 10 R, 13 R, 14 S, 17 R)$-17-[(E,2R,5S)-5-etil-6-metilept-3-en-2-il]10,13-dimetil-2,3,4,7,8,9,11,12,14,15,16,17-dodecaidro- $1 H$-ciclopenta[ $a]$ fenantren-3-ol; 3. - Sitosterol: 17-(5-Etil-6-metileptan-2-il)-10,13-dimetil-2,3,4,7,8,9,11,12,14,15,16,17dodecaidro- $1 H$-ciclopenta $[a]$ fenantren-3-ol.

Fig. 3 - Chemical structures of compounds with m/z 401 (Campesterol), m/z 413 (Stigmasterol), and m/z 415 (Sitosterol) from Talinum paniculatum. and low toxicity on BHK-21 cells were observed. Furthermore, EtOAc against $E$. aerogenes $(\mathrm{SI}=4.33), E$. coli $(\mathrm{SI}=9.71)$, and $C$. albicans $(\mathrm{SI}$ $=2.33)$, and LE against $S$. marcescens $(\mathrm{SI}=5.52)$ and $S$. aureus $(\mathrm{SI}=$ 2.76) also exhibited good SI results.

Infectious diseases remain the leading cause of morbidity and mortality all over the world ${ }^{37}$. Reinforcing this serious issue, the increasing emergence of multidrug-resistant microorganisms and their dissemination have caused a disturbance because of high morbidity and mortality rates associated with infectious diseases caused by them. Multidrug-resistant microorganisms are also one of the greatest problems in hospital environment, where frequent and indiscriminate use of antibiotics occurs and hence contributed to $i^{3}$. Meanwhile, few antimicrobial agents have been launched on the market, aggravating this public health issue. Consequently, the discovery of new antimicrobials to treat infections caused by multidrug resistant microorganisms is highly desirable and a challenging task ${ }^{22}$.

The LE, HX and EtOAc fractions from T. paniculatum showed significant inhibitory activity in vitro against microorganisms of great medical importance. Among these, $C$. albicans, a fungus that causes opportunistic infections and it is often associated to nosocomial infections ${ }^{15}$. DALLEAU et al. $(2008)^{10}$ observed in vitro activity of different terpenes reducing the biofilm formation in the Candida species. In our study, HX fraction (high terpene content) from $T$. paniculatum showed significant inhibitory activity against $C$. albicans $(31.2 \mu \mathrm{g} / \mathrm{mL})$.

Multidrug-resistant $S$. aureus is one of the most common causes of nosocomial infections, representing a public health concern. In recent years, it has been performed a screening of plants as possible sources new compounds to treat diseases caused by this microorganism ${ }^{21,35}$. GALLUCCI et al. (2010) reported in vitro inhibitory effect of terpenes against methicillin resistant Staphylococcus aureus (MRSA) and against the formation of biofilms ${ }^{12}$. Similarly, we observed inhibitory activity against $S$. aureus for both $\mathrm{HX}$ and EtOAc fractions from T. paniculatum, which presented terpenes and phytosteroids as major components.

Species belonging to the genus Staphylococcus are known as the most common causes of a variety of skin infections in humans (e.g. erysipelas, cellulitis, impetigo, and eczema) and also were associated with wound contamination ${ }^{23}$. As shown here, the good activity of the LE (MIC value of $500 \mu \mathrm{g} / \mathrm{mL}$ ) and fractions (MIC values of $250 \mu \mathrm{g} / \mathrm{mL}$ ) from $T$. paniculatum against $S$. aureus may establish, at least in part, a link between the use of $T$. paniculatum leaves for the topical treatment of skin infections and wounds, as foreseen in previous studies ${ }^{4}$, and in the results from our study. However, it is noteworthy that additional studies regarding the safety and efficacy of $T$. paniculatum must be performed and, outside of the scope of this work, justify, advise, or confirm the popular use of this plant.

Featuring similar clinical and epidemiological importance than $S$. aureus and $C$. albicans, the bacteria $E$. coli, S. marcescens, $P$. aeruginosa, and $P$. mirabilis are usually found in the human microbiome and, under certain predisposing factors, they are responsible for a range of infections. Due to the intense acquisition and dissemination of genes related to multidrug resistance, infectious diseases caused by these microorganisms have also received notable attention ${ }^{11,14}$. In the 


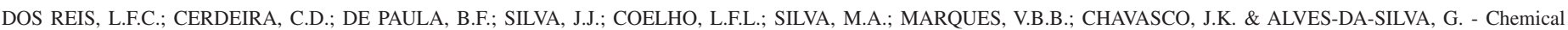
characterization and evaluation of antibacterial, antifungal, antimycobacterial, and cytotoxic activities of Talinum paniculatum. Rev. Inst. Med. Trop. Sao Paulo, 57(5): 397-405, 2015.

present study, E. coli, $S$. marcescens, $P$. aeruginosa, and $P$. mirabilis were inhibited in vitro by low concentrations of $\mathrm{HX}$ and EtOAc (from 31.2 to $500 \mu \mathrm{g} / \mathrm{mL})$.

Excellent inhibitory activity (MIC of $70 \mu \mathrm{g} / \mathrm{mL}$ ) was also observed for the EtOAc against E. aerogenes, an emerging opportunistic and nosocomial pathogen. The infectious diseases caused by Enterobacter aerogenes have reached considerable prevalence worldwide, becoming a public health problem, mainly because of its resistance to antimicrobial agents $^{6,19}$. Additionally, E. aerogenes is also considered a food pathogen, often associated with food contamination, with serious consequences for human health ${ }^{33}$. The LE from $T$. paniculatum was inactive at the concentration tested $(50 \mathrm{mg} / \mathrm{mL})$ against $M$. tuberculosis and $M$. bovis, by agar diffusion assay.

In summary, since the crude leaf extract and fractions hexane and ethyl acetate from T. paniculatum presented outstanding antimicrobial activity, and low toxicity, they show antimicrobial potential. Nevertheless, further studies must be performed, either aiming the isolation of compounds in search for new antimicrobials or evaluating the safety and efficacy of $T$. paniculatum LE for a possible use in herbal medicine. Although T. paniculatum (crude leaf extract) showed low MIC against $S$. aureus, further studies are needed to investigate a possible synergism between $T$. paniculatum LE and antibiotics used to treat resistan strains (e.g. MRSA) .

\section{RESUMO}

\section{Caracterização química e avaliação das atividades antibacteriana, antifúngica, antimicobacteriana e citotóxica de Talinum paniculatum}

Neste estudo foi avaliada a bioatividade de Talinum paniculatum, planta amplamente utilizada na medicina popular. $\mathrm{O}$ extrato das folhas (EF) de T. paniculatum foi obtido por percolação com etanol-água e, em seguida, submetido à partição líquido-líquido, obtendo-se as frações hexânica $(\mathrm{HX})$, acetato-etílica (AcOEt), butanólica $(\mathrm{BuOH})$ e aquosa (Aq). A triagem para a atividade antimicrobiana do EF e de suas frações foram avaliadas in vitro através do método de microdiluição em caldo contra treze micro-organismos patogênicos e não-patogênicos e, a atividade antimicobacteriana, foi avaliada através do teste de difusão em ágar. As concentrações citotóxicas $\left(\mathrm{CC}_{90}\right)$ do $\mathrm{EF}$ e das frações $\mathrm{HX}$ e AcOEt foram obtidas sobre células da linhagem BHK-21 através do ensaio de redução do MTT. O EF mostrou atividade contra Serratia marcescens e Staphylococcus aureus, com valores de concentração inibitória mínima (CIM) de 250 e $500 \mu \mathrm{g} / \mathrm{mL}$, respectivamente. Além disso, HX demonstrou excelente atividade contra Micrococcus luteus e Candida albicans com uma CIM de $31,2 \mu \mathrm{g} / \mathrm{mL}$, em ambos os casos. Contra Escherichia coli, a CIM para AcOEt foi também de 31,2 $\mu \mathrm{g} / \mathrm{mL}$. Por outro lado, as frações $\mathrm{BuOH}$ e Aq foram inativas contra todos os micro-organismos testados, assim como o EF contra Mycobacterium tuberculosis e Mycobacterium bovis. Campesterol, estigmasterol e sitosterol foram as estruturas propostas como principais compostos presentes no EF e nas frações HX e AcOEt, evidenciadas através de espectrometria de massas. Portanto, o extrato da folha e as frações HX e AcOEt provenientes de T. paniculatum apresentaram potencial como possíveis fontes de compostos antimicrobianos, HX principalmente, por ter apresentado uma baixa toxicidade sobre células BHK-21 com um bom índice de seletividade ( $\mathrm{IS}=\mathrm{CC}_{90} / \mathrm{MIC}$ ) de 17,72 contra $C$. albicans.

\section{ACKNOWLEDGEMENTS}

The authors acknowledge Dr. Marcelo Polo for the identification of the plant material. This research was supported by the Coordenação de Aperfeiçoamento de Pessoal de Nivel Superior (CAPES/Brasil).

\section{AUTHOR DISCLOSURE STATEMENT}

The authors declare that there are no conflicts of interest.

\section{ETHICS STATEMENT}

This study did not involve any endangered or protected species and no specific permits were required for the described studies. Botanical material from $T$. paniculatum was collected in a particular area, with access permitted to researchers.

\section{AUTHORS' CONTRIBUTION}

LFCR designed the study; carried out the plant collection; prepared the hydroalcoholic leaf extract (LE) and fractions from T. paniculatum; performed mass spectrometry (MS) analysis; constructed the figures from 3 to 9; helped in the antimicrobial evaluation and helped drafting the manuscript. CDC participated in the study design; evaluated the antimicrobial activity of $T$. paniculatum; wrote the manuscript; constructed Tables (1 and 2) and Figures (1 and 2); performed data organization and data analysis (statistical analysis); conducted manuscript revision and manuscript finalizing in its final form. BFP carried out the plant collection; helped prepare hydro-alcoholic leaf extract and fractions and helped in the antimicrobial evaluation. JJS helped in the antimicrobial evaluation. LFLC evaluated the cytotoxic activity of $T$. paniculatum. MAP contributed with reagents/analytical tools. VBBM performed MS analysis. JKC supervised antimicrobial evaluation. GAS selected the plant used in this study; came up with the study and participated in its design and coordination. All the authors read and approved the final manuscript.

\section{SUPPLEMENTARY DATA}

First and second mass analyzers scan of EtOAc, HX, and EF from T. paniculatum (Figs. 4, 5, 6, 7, 8, and 9).

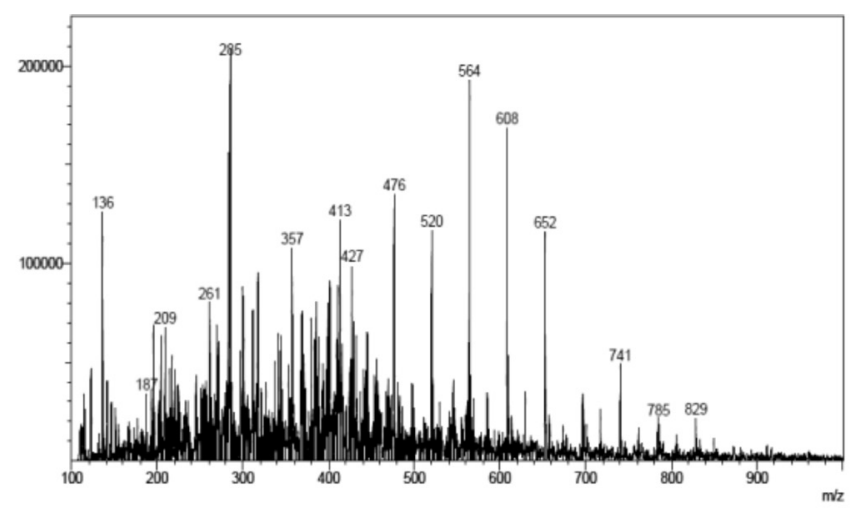

Fig. 4 - First mass analyzers scan of the EtOAc from Talinum paniculatum. 


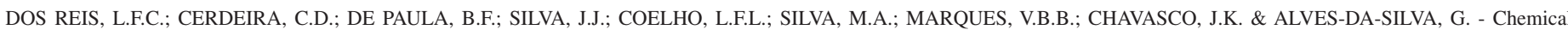
characterization and evaluation of antibacterial, antifungal, antimycobacterial, and cytotoxic activities of Talinum paniculatum. Rev. Inst. Med. Trop. Sao Paulo, 57(5): 397-405, 2015.

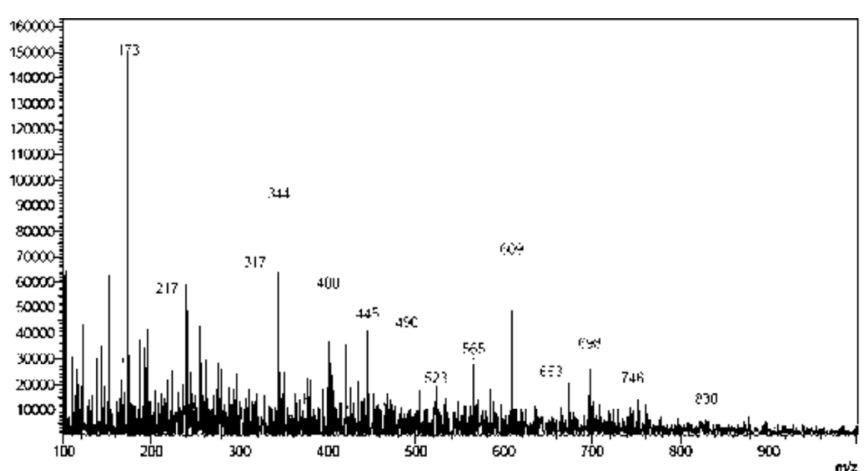

Fig. 5 - First mass analyzers scan of the HX from Talinum paniculatum.

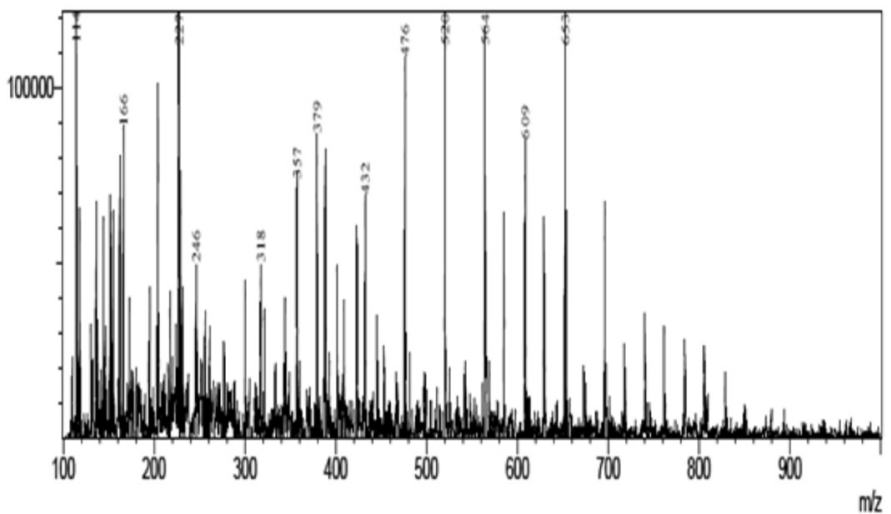

Fig. 6 - First mass analyzers scan of the EF from Talinum paniculatum.

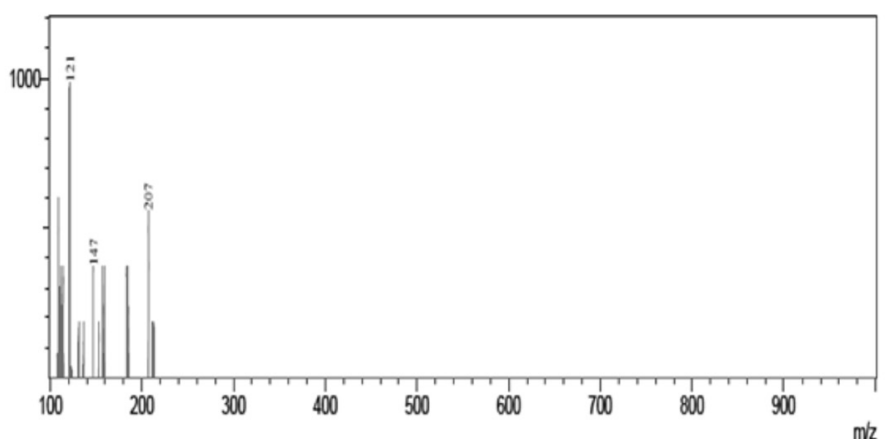

Fig. 7 - Spectra obtained from compound of m/z 401 from Talinum paniculatum.

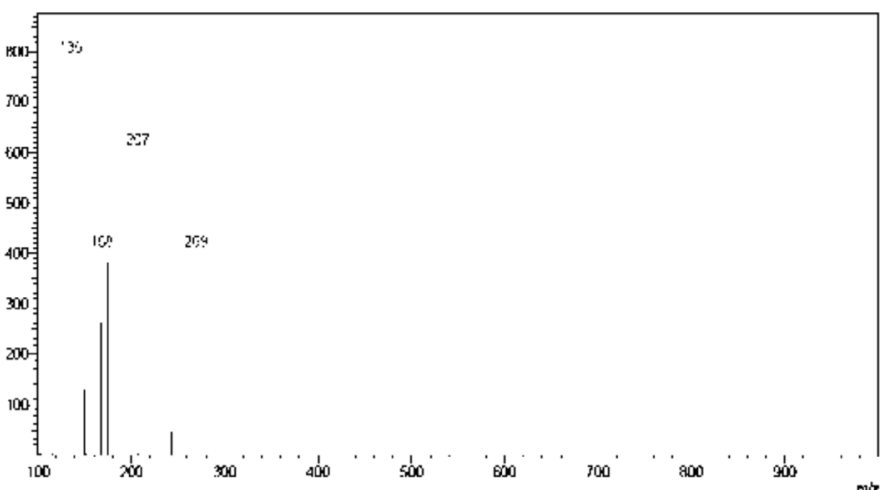

Fig. 8 - Spectra obtained from compound of m/z 413 from Talinum paniculatum.

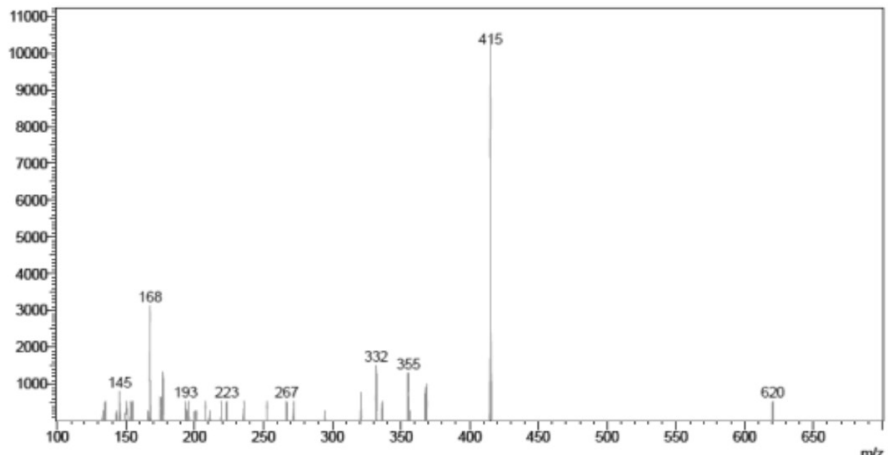

Fig. 9 - Spectra obtained from compound of m/z 415 from Talinum paniculatum.

\section{REFERENCES}

1. Awouafack MD, McGaw LJ, Gottfried S, Mbouangouere R, Tane P, Spiteller M, et al. Antimicrobial activity and cytotoxicity of the ethanol extract, fractions and eight compounds isolated from Eriosema robustum (Fabaceae). BMC Complement Altern Med. 2013;13:289.

2. Bonjar GHS. New approaches in screening for antibacterials in plants. Asian J Plant Sci. 2004:3:55-60.

3. Brown ED. Is the GAIN Act a turning point in new antibiotic discovery? Can J Microbiol. 2013;59:153-6.

4. Caribe J, Campos JM. Plantas que ajudam o homem: guia prático para época. São Paulo: Cultrix/Pensamento; 1991.

5. Chavasco JM, Prado e Feliphe BHM, Cerdeira CD, Leandro FD, Coelho LFL, da Silva JJ, et al. Evaluation of antimicrobial and cytotoxic activities of plant extracts from Southern Minas Gerais cerrado. Rev Inst Med Trop Sao Paulo. 2014;56:13-20.

6. Chen L, Chavda KD, Melano RG, Jacobs MR, Koll B, Hong T, et al. Comparative genomic analysis of KPC-encoding pKpQIL-like plasmids and their distribution in New Jersey and New York hospitals. Antimicrob Agents Chemother. 2014;58:2871-7. doi:10.1128/AAC .00120-14.

7. Clinical and Laboratory Standards Institute. Methods for dilution antimicrobial susceptibility tests for bacteria that grow aerobically. Approved standard M7-A6. $6^{\text {th }}$ ed. Wayne: CLSI; 2003.

8. Clinical and Laboratory Standards Institute. Reference method for broth dilution antifungal susceptibility testing of yeasts. Approved standard M27-A3. $3^{\text {rd }}$ ed. Wayne: CLSI; 2008

9. Clinical and Laboratory Standards Institute. Susceptibility testing of mycobacteria, nocardiae, and other aerobic actinomycetes. Approved standard M24- A2. $2^{\text {nd }}$ ed. Wayne: CLSI; 2008.

10. Dalleau S, Cateau E, Bergès T, Berjeaud JM, Imbert C. In vitro activity of terpenes against Candida biofilms. Int J Antimicrobial Agents. 2008;31:572-6.

11. Forsberg KJ, Reyes A, Wang B, Selleck EM, Sommer MOA, Dantas G. The shared antibiotic resistome of soil bacteria and human pathogens. Science. 2012;31:1107-11.

12. Gallucci N, Oliva M, Carezzano E, Zygadlo J, Demo M. Terpenes antimicrobial activity against slime producing and non-producing staphylococci. Mol Med Chem. 2010;21:132-6.

13. Hemaiswarya S, Kruthiventi AK, Doble M. Synergism between natural products and antibiotics against infectious diseases. Phytomedicine. 2008;15:639-52.

14. Higuchi CK, Corrêa CR, Rall VLM, Fernandes A Jr. Evaluation of the diramic system for urine cultures. Braz J Microbiol. 2006:37:221-4. 
DOS REIS, L.F.C.; CERDEIRA, C.D.; DE PAULA, B.F.; SILVA, J.J.; COELHO, L.F.L.; SILVA, M.A.; MARQUES, V.B.B.; CHAVASCO, J.K. \& ALVES-DA-SILVA, G. - Chemical characterization and evaluation of antibacterial, antifungal, antimycobacterial, and cytotoxic activities of Talinum paniculatum. Rev. Inst. Med. Trop. Sao Paulo, 57(5): 397-405, 2015.

15. Hofer U. Sugar-coating virulent Candida albicans. Nat Rev Microbiol. 2013;11:360.

16. Hong-Fang J, Xue-Juan L, Hong-Yu Z. Natural products and drug discovery. Can thousands of years of ancient medical knowledge lead us to new and powerful drug combinations in the fight against cancer and dementia? EMBO Rep. 2009;10:194-200.

17. Kleymann G, Werling HOA. Generally applicable, high-throughput screeningcompatible assay to identify, evaluate, and optimize-antimicrobial agents for drug therapy. J Biomol Screen. 2004;9:578-87.

18. Koehn FE, Carter GT. The evolving role of natural products in drug discovery. Nat Rev Drug Discov. 2005;4:206-20.

19. Martínez D, Rodulfo HE, Rodriguez L, Caña LE, Medina B, Guzman M, et al. First report of metallo- $\beta$-lactamases producing Enterobacter spp. strains from Venezuela. Rev Inst Med Trop Sao Paulo. 2014;56:67-9.

20. Martins ER, Castro DM, Castellani DC, Dias JE. Plantas medicinais. Viçosa: Ed. Universidade Federal de Viçosa; 2000.

21. Mattana CM, Satorres SE, Sosa A, Fusco M, Alcará LE. Antibacterial activity of extracts of Acacia aroma against methicillin-resistant and methicillin-sensitive Staphylococcus. Braz J Microbiol. 2010;41:581-7.

22. Morse SS. Factors in the emergence of infectious diseases. Emerg Infect Dis. 1995;1:715.

23. Nadarajah J, Lee MJ, Louie L, Jacob L, Simor AE, Louie M, et al. Identification of different clonal complexes and diverse amino acid substitutions in penicillinbinding protein 2 (PBP2) associated with borderline oxacillin resistance in Canadian Staphylococcus aureus isolates. J Med Microbiol. 2006;55:1675-83.

24. Panizza S. Plantas que curam: cheiro de mato. 15. ed. São Paulo: IBRASA; 2008.

25. Patwardhan B, Vaidya ADB. Natural products drug discovery: accelerating the clinical candidate development using reverse pharmacology approaches. Indian J Exp Biol. 2010;48:220-7.

26. Pereira RJ, Cardoso MGJ. Metabólitos secundários vegetais e benefícios antioxidantes. J Biotec Biodivers. 2012;3:146-52.
27. Protopopova M, Hanrahan C, Nikonenko B, Samala R, Chen P, Gearhart J, et al Identification of a new antitubercular drug candidate, SQ 109, from a combinatorial library of 1,2-ethylenediamines. J Antimicrob Chemother. 2005;56:968-74.

28. Ramos MPO, Silva GDF, Duarte LP, Miranda RRS, Souza GHB, Belinelo VJ, et al Antinociceptive and edematogenic activity and chemical constituents of Talinum paniculatum Willd. J Chem Pharm Res. 2010;2:265-74

29. Ríos JL, Recio MC. Medicinal plants and antimicrobial activity. J Ethnopharmacol $2005 ; 100: 80-4$

30. Scalbert A. Antimicrobial properties of tannins. Phytochemistry. 1991;30:3875-83.

31. Schenkel EP, Gosmann G, Athayde ML. Saponinas. In: Simões CM, Schenkel EP, Gosmann G, Mello JCP, Mentz LA, Petrovick PR, organizadores. Farmacognosia: da planta ao medicamento. 3a ed. Porto Alegre: Ed. UFRGS/Ed. UFSC; 2001. p. 597-619.

32. Silva MC, Gayer CR, Lopes CS, Calixto NO, Reis PA, Passaes CP, et al. Acute and topic anti-edematogenic fractions isolated from the seeds of Pterodon pubescens. J Pharm Pharmacol. 2004;56:135-41.

33. Techathuvanan C, Reyes F, David JR, Davidson PM. Efficacy of commercial natural antimicrobials alone and in combinations against pathogenic and spoilage microorganisms. J Food Prot. 2014;77:269-75.

34. Thanamool C, Papirom P, Chanlun S, Kupittayanant S. Talinum paniculatum (Jacq.) Gertn: a medicinal plant with potential estrogenic activity in ovariectomized rats. Int J Pharm Pharm Sci. 2013;5:478-85.

35. Vilar JB, Ferreira FL, Ferri PH, Guillo LA, Chen Chen L. Assessment of the mutagenic, antimutagenic and cytotoxic activities of ethanolic extract of araticum (Annona crassiflora Mart. 1841) by micronucleus test in mice. Braz J Biol 2008;68:141-7.

36. World Heatlh Organization. Report on infectious diseases. Geneva:WHO; 2012.

37. Yulia, Wientarsih I, Razier-A N. The study of phytochemistry of Java ginseng compare to Korean ginseng. J Agric Rural Dev Trop Subtrop. 2006;(Suppl. 88):45-9.

Received: 25 August 2014

Accepted: 21 January 2015 


\section{LIBRARY OF THE \\ SÃO PAULO INSTITUTE OF TROPICAL MEDICINE}

Website: http://www.imt.usp.br/sobre-o-imtsp/biblioteca

Address: Biblioteca do Instituto de Medicina Tropical de São Paulo da Universidade de São Paulo Av. Dr. Enéas de Carvalho Aguiar, 470.

05403-000 - São Paulo - SP - Brazil.

Telephone: 5511 3061-7003
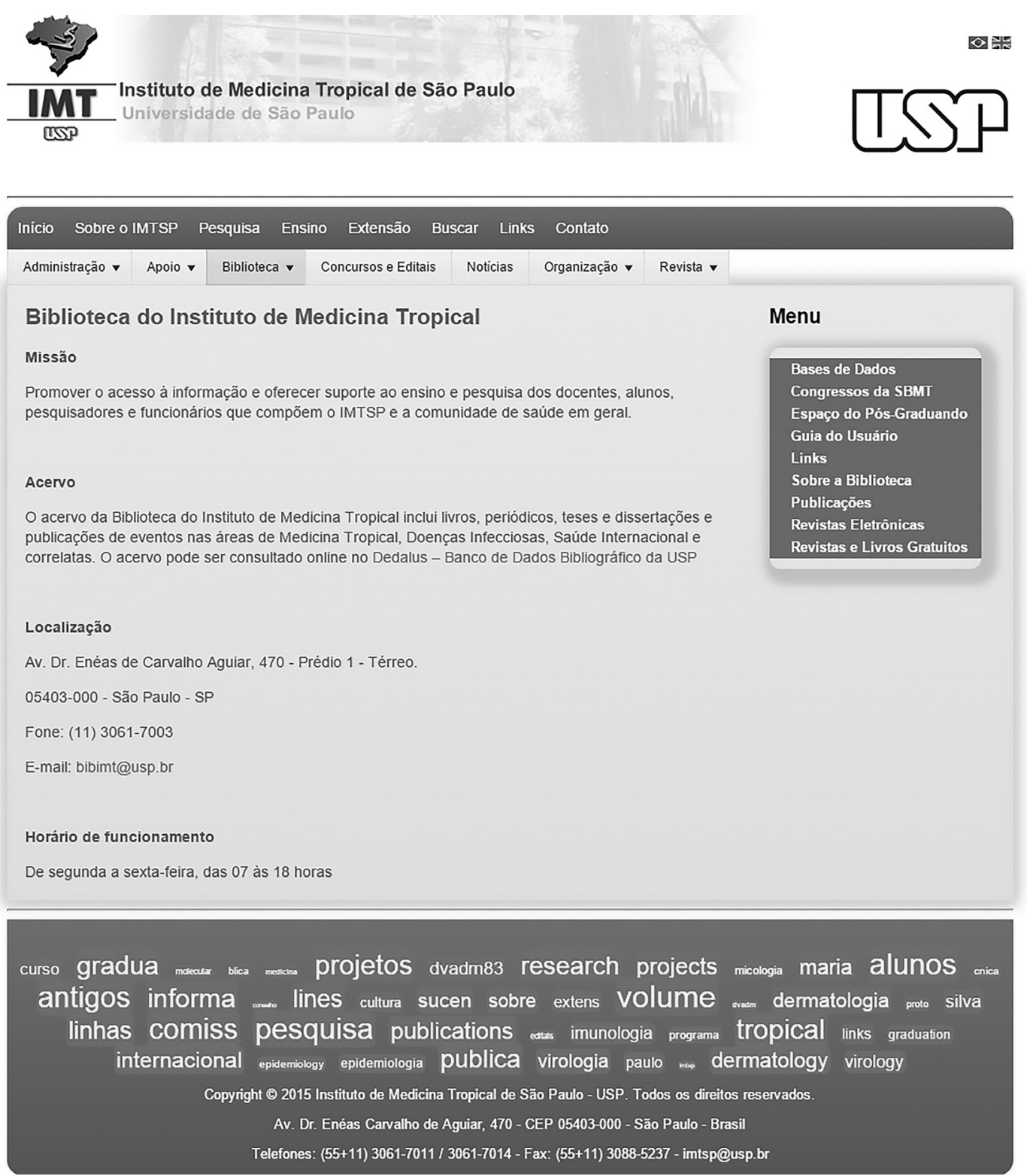

The Library of the São Paulo Institute of Tropical Medicine (IMTSP Library) was created on January 15, 1959 in order to serve all those who are interested in tropical diseases.

The IMTSP Library has a collection consisting of books, theses, annals of congresses, journals, and reference works.

The collection of the Library can be searched through the USP Bibliographic Database - Dedalus at the URL http://200.144.190.234/F 